\title{
The Ethnic Labelling of a Genre Gone Global: A Distant Comparison of African-American and African Chick Lit
}

\begin{abstract}
Originally defined as an Anglo-American phenomenon, starting with Helen Fielding's best-selling novel Bridget Jones's Diary (1996), chick lit has spread rapidly across various linguistic and cultural markets. There is a broad consensus that this is a transfer from the centre to the periphery, from the original genre to numerous adapted subgenres and variations. For the latter, the problematic term "'ethnic' chick lit," which in the broadest sense includes all chick lit by authors with non-Western sociocultural backgrounds, has become established. The implicit (re-vision, recovery) and explicit (circulation, collage) comparative strategies introduced by Susan Stanford Friedman serve as a methodological framework for analysing such practices of ethnic labelling. These strategies are applied not through a close reading of primary literature but through a distant reading, or rather comparison, of the Anglo-American chick-lit label with two of its socalled "ethnic" subgenres or variations: African-American and African chick lit. A re-visioning of Anglo-American chick lit through a recovery of African-American chick lit, as well as a focus on the label's circulation in Africa, resulting in a collage of African chick lit, demonstrates that the label's dissemination was not as linear as has been suggested by the dominant discourse of chick lit gone global.
\end{abstract}

Keywords: chick lit, ethnicity, literary genres, women's fiction, world literature

Since the 1990s, there has been a lot of controversy about comparative literature in the global era, especially with regard to world literature. ${ }^{1}$ In a qualitative way, world literature has been defined as a canon, an established body of classics or masterpieces which has the reputation of being relatively andro- and Eurocentric, a "white-male affair in large part" (Damrosch 2003, 16, paraphrasing Guillory 1993, 32). From a strictly quantitative point of view, world literature would be the sum total of the world's literatures, which remains, of course, an abstraction. But nonetheless, it is the quantitative approach - the inclusion of more and more literatures - that has challenged and even troubled our discipline lately. This dis-

1 While researching and writing this article, I was supported by a doctoral fellowship from the Austrian Academy of Sciences.

Ә Open Access. (๑) 2020 Sandra Folie, published by De Gruyter. (c) BY-NC-ND This work is licensed under a Creative Commons Attribution-NonCommercial-NoDerivatives 4.0 License. 
cord is perhaps represented most famously by Gayatri Spivak in her book Death of a Discipline (2003), in which she takes a rather pessimistic view of the increasing anglophonicity of globally oriented comparative literature studies. Ten years later, Emily Apter (2013) opted, in Against World Literature, for world literatures in the plural, and so does Aamir R. Mufti (2016) with the call of his Forget English! These scholars are opposed not to the globalization of world literature (studies) in general, but to the Anglocentric and monolingual way in which it generally seems to be handled. Apart from the conclusion that comparative literature always seems to be in crisis (Saussy 2014), one gets the impression that it is primarily the methodological frame - the how-to - that has to be (re)negotiated. As Franco Moretti (2000, 54-55) ponders in his controversial essay "Conjectures on World Literature," "the question is not really what we should do - the question is how. What does it mean, studying world literature? How do we do it?” In response, he introduces distant reading as opposed to the traditional method of close reading. Although "distant reading" is often used these days as a synonym for "digital humanities," it started out as “a patchwork of other people's research" (Moretti 2000, 57), permitting literary scholars "to focus on units that are much smaller or much larger than the text: devices, themes, tropes - or genres and systems" (57). Moretti initially studied and compared the development of the novel as it was described in several international literary histories. The conclusion of this synthesis was what he called "the law of literary evolution": "in cultures that belong to the periphery of the literary system (which means: almost all cultures, inside and outside Europe), the modern novel first arises not as an autonomous development but as a compromise between a western formal influence (usually French or English) and local materials" (58). Within such a centre/periphery model, evolutions or modernizations always seem to start in the West, spreading like a virus or a remedy - depending on the perspective - to every part of the globe. ${ }^{2}$ This does not mean that sympathies lie with the West but that a Eurocentric perspective dominates; such is the case in discussions of chick lit, the genre of contemporary women's fiction (or rather, a label for a form of it) which is the main topic of this article.

2 Pascale Casanova $(1999,15)$, another prominent scholar to draw on the centre/periphery approach, claimed in La République mondiale des lettres that Paris (representing French literature in general) is "le 'méridien de Greenwich' littéraire," or, in other words, the primary centre of the literary world. 


\section{Chick lit gone global, or The ethnicization of a genre}

Although the term "chick lit" has been around since the 1980s - when it was a slightly derogatory name for Elaine Showalter's course on the female literary tradition at Princeton University (Betterton 1988, 113) - it took another decade until it became widely known in the context of contemporary women's fiction. First used thus by Cris Mazza and Jeffrey DeShell (1995) in the title of their short-story collection, which, according to Mazza $(2006,19)$, "transgressed the mainstream or challenged the status quo," chick lit has ironically become known as a description for the mainstream or status quo it was initially supposed to undermine: popular fiction about "career girls looking for love" (19), first and foremost Bridget Jones and Carrie Bradshaw, who both started life as the main characters of a newspaper column but had their significant breakthrough when published in novel form and adapted for the screen. Originally defined as an Anglo-American phenomenon, chick lit has spread rapidly across various linguistic and cultural markets. Its worldwide popularity has repeatedly been interpreted as a transfer from the centre to the periphery, from the original genre to numerous adapted subgenres or variations. With her New York Times article "The Chick-Lit Pandemic," Rachel Donadio started the discussion about chick lit being a global phenomenon. The article opens:

\footnotetext{
In the near decade since Bridget Jones first hit the world stage - endearing, hung over and running late for work - an international commuter train of women has been gathering speed close behind. From Mumbai to Milan, Gdansk to Jakarta, regional varieties of chick lit have been sprouting, buoyed by the demographic that's both their subject and readership: 20and 30-something women with full-time jobs, discretionary income and a hunger for independence and glamour. (Donadio 2006)
}

Several years later, the discourse of chick lit gone global was taken up by the academic community. Drawing on the example of Chinese chick lit, more precisely Wei Hui's novel Shanghai Baby (1999), Eva Chen (2012, 214) demonstrates that chick lit has "gone global"; so does Radha S. Hegde $(2014,98)$ when she proclaims that "global 'chick lit' is springing up in Latin America, China, India, and Eastern Europe, with similar themes that unite young urban women in a global community of consumers." A more critical view is to be found in Sandra Ponzanesi's analysis of Indian chick lit:

though the genre reveals common patterns of denomination, linked to consumerism, female upward mobility and rapid urbanization, it presents inherent features linked to the country- 
specific economic development, particular histories of feminism and locally inflected responses to commoditized patterns of behaviour. So to speak of global chick lit might be too simplistic and celebratory. (Ponzanesi 2014, 176)

All of these authors emphasize that there are different varieties of chick lit in different parts of the world. Like Moretti, they do not write of a simple genre-export such that the product moves from one place to another without any local adaptation. But, with the exception of Ponzanesi, there still remains a tendency in their arguments "to flatten the distinction between an Anglo-American version on the one hand and 'the global chick lit' on the other," as Sorcha Gunne $(2016,244)$ has accurately observed.

This reproduction of the West vs the rest binary is also found in the common terminological distinction between "chick lit" and "'ethnic' chick lit," which has primarily been used for chick lit from and about ethnic minorities in the US, especially for African- and Hispanic/Latina-, but also for Asian-American chick lit. According to Cathy Yardley (2006, 25), who wrote a manual on how to write a chicklit novel, these flourishing subgenres show "the universality of Chick Lit issues and elements" and, at the same time, "give mainstream readers [whom Yardley seems to equate with white Western readers] a taste of a culture completely different from their own, appealing to women across the ethnic spectrum." Later on, global, quite often postcolonial variations were also considered to be "ethnic" chick lit (Ponzanesi 2014, ch. 6). In the broadest sense, the label includes all chick lit whose authors or protagonists have non-Western sociocultural backgrounds. One major criterion, however, seems to be the concept of race/ethnicity, which often correlates with skin colour. There are at least three reasons why this terminological distinction is problematic. First, it suggests that white Anglo-American chick lit is not ethnic. ${ }^{3}$ Second, it indicates a hierarchy between the prototypical, or even original, chick-lit genre and the adapted subgenres or varieties subsumed under the term "'ethnic' chick lit." Third, this subsumption homogenizes the wide field of contemporary women's fiction around the globe. ${ }^{4}$

3 What Richard Dyer $(2008,1)$ observed with regard to racial imagery also seems to be applicable to the ethnic imagery applied in "ethnic" chick lit: "As long as race is something only applied to non-white people, as long as white people are not racially seen and named, they/we function as a human norm. Other people are raced, we are just people.”

4 This line of argument - exemplified by African-American and African chick lit (among other examples), though based on another methodological framework (intersectionality) - is also put forward in Folie (2018; in German). 


\section{Distantly comparing "ethnic" chick lit(s)}

Nowadays, in comparative literature studies as well as in other disciplines engaged with transnational research, a circulation model is favoured over a centreperiphery approach. Circulation models are based on current theories of travelling cultures, transnational cultural traffic, and hybridity. In her article "World Modernisms, World Literature, and Comparativity," Susan Stanford Friedman (2012) suggests four potential comparative strategies for research on a planetary scale, which take into account the centre-periphery as well as the circulation model. The first two - re-vision and recovery - she describes as implicit forms of comparison. They help to reflect the ways in which the centre-periphery model was constituted in the first place. The latter two - circulation and collage - represent more explicit forms of comparison, as they scrutinize the dominant centreperiphery relationships and focus on "multiple centers and conjunctures across the globe" (Friedman 2012, 507-508). Through these comparative strategies, which are in practice often interwoven, I will describe my field of research, chick lit - a supposedly global phenomenon whose globality has been, quite inadequately, subsumed under the term “'ethnic' chick lit.” I am going to do this in a rather distant mode, by analysing not primary literature but the labelling of contemporary women's fiction as "ethnic" chick lit. I would not call my approach a distant reading, but perhaps one of distantly reading/comparing, as it is a comparative metastudy about gendered and ethnicized labelling practices in various media.

\subsection{Re-vision and recovery: African-American chick lit}

Re-vision, the first strategy, "implies seeing from a different vantage point, that is, different from how one has seen before" (Friedman 2012, 508). Chick lit has been perceived as an Anglo-American genre of contemporary women's fiction, starting with Helen Fielding's bestseller novel Bridget Jones's Diary in 1996. Journalists (e.g. Skurnick 2003) and scholars (e.g. Peitz 2010) have tried to establish a genre configuration by analysing prototypical chick-lit novels. This configuration became extended and, I would argue, undermined by the emergence of various subgenres. Originally, chick lit was defined by its young protagonists, educated single women in their twenties or thirties who lived in a Western metropolis, where they struggled with their jobs and private lives until they finally met Mr Right. Soon, there was hen or lady lit for women over forty, and teen or young adult chick lit for women under twenty; subgenres like bride or mum lit left the protagonists' obligatory single status and hunt for men behind. "Ethnic" chick lit dis- 
missed the characters' Western sociocultural backgrounds, and often their whiteness. The emergence of many more subgenres that go beyond the rather narrow chick-lit formula ${ }^{5}$ indicates the expansion of the genre in the direction of a cultural phenomenon (Missler 2016) or a catch-all term and label for several mouldings of contemporary women's fiction (Folie and Kreuter 2018, 48-56). "Ethnic" chick lit's alleged subgenre status proves equally questionable, as does the genre status of chick lit once the archaeological strategy of recovery is applied. The strategy of recovery "does more than expand the archive; it also asks how the archive [...] got established in the first place as a Eurocentric framework that has steadfastly marginalized non-Western expressive cultures" (Friedman 2012, 510). By recovering African-American chick lit, one of several supposedly ethnic subgenres of AngloAmerican chick lit, I will draw attention to the severe imbalance caused by the linkage of ethnicity with literary subclassification.

Imelda Whelehan (2005, 17-18), in her book The Feminist Bestseller, claims what is according to her "probably already clear to the reader": "feminist bestsellers and chick lit are predominantly the work of white, middle-class, heterosexual women." She states that she thought about including "black writings" but it seemed somehow too far-fetched because, as she writes, she did not "know of any black women writers who have produced work that fits into the broad category of the feminist bestseller" (18). Astonishingly, Whelehan herself, however, quotes Terry McMillan's Waiting to Exhale (1992), which, in other secondary sources, is described as the precursor and prototype of African-American (Guerrero 2006) or "ethnic" (Hedrick 2015, 3) chick lit. Along with Terry McMillan, Connie Briscoe and Benilde Little are considered the "midwives of black chick lit" (Lee 2005). If black African-American chick lit is defined as a subgenre of Anglo-American chick lit, which is said to have come into existence several years later with Fielding's Bridget Jones's Diary (1996), the supposition that the chick-lit tradition became "whitened" seems reasonable (Konchar Farr 2009, 203). Apparently, we have not overcome Eurochronology yet, a spatio-temporal concept according to which innovation and originality usually start in the West, from where they may or may not travel to the always already late rest (Prendergast 2004, 6). That authors of African-American chick lit, who are usually born in and usually live in the US, are considered to belong to "the rest" illustrates that Eurochronology is not only, and perhaps not even primarily, a spatio-temporal but also a highly racialized concept. However, these ethnic labelling practices should not distract from the fact that "the West" - in this case represented by Anglo-American chick

5 Lists of subgenres are to be found, for example, in Vnuk (2005); Ferriss and Young (2006, 5-6); Yardley (2006, 17-28); Missler (2016, 33-34). 
lit - is itself an extremely vague category. According to Sorcha Gunne (2016, 250), "to yolk [sic] together British and American chick lit under the Anglo-American umbrella creates a category of the 'west' that is similarly problematic to the tendency to categorize chick lit from beyond this Anglo-American sphere as 'global' and by implication 'the rest."” Furthermore, the Anglo-American category, if used exclusively for British and US-American literature, overshadows chick lit by authors from other English-speaking countries like, for example, Ireland. Although the novel Watermelon - published in 1995, one year before Bridget Jones's Diary - by the Irish author Marian Keyes is considered to be one of the first chick-lit novels, it has hardly ever been mentioned as a genre-defining prototype, in contrast to its US and UK counterparts. ${ }^{6}$

Admittedly, the ways in which scholars describe stories of origins and genre hierarchies seem to change, at least in part. Heike Missler (2016), in her monograph on chick lit, describes African American chick-lit novels, notably McMillan's Waiting to Exhale, more appropriately as “avant-la-lettre” (15) or as "forerunners of the genre, which have conveniently been subsumed under the heading of chick lit for marketing purposes" (154). Moreover, she lists Marian Keyes alongside Helen Fielding and Candace Bushnell as one of "the godmothers of the genre" (18). Nevertheless, despite this delinquent recuperative tendency, the awkward questions remain: why not call McMillan a godmother of the genre, in the sense of a possible starting point? Why not call Fielding and Bushnell midwives of white chick lit, or their books variations or even subgenres of black chick lit? Richard Dyer's (2008, xiii) general observation that "white people have had so very much more control over the definition of themselves and indeed of others than have those others" might be able to provide a partial answer. However, individual acts of resistance like Guerrero's (2006) coinage of the alternative label "sistah lit" and McMillan's dismissal of the "chick-lit” label (in Wright 2016) point to an alternative, and certainly more empowering answer.

\subsection{Circulation and collage: African chick lit}

The re-visioning of chick lit through the recovery of African-American chick lit already indicates more complex ways of circulation than a transfer from the supposedly dynamic Anglo-American centre to the supposedly static ethnic periphery.

6 This is, at least, the case in the standard works on chick lit (e.g. Ferriss and Young 2006; Peitz 2010) and in the better-known definitions, both academic (e.g. Baldick 2015) and popular such as the "Chick Lit" article on Wikipedia (2018). 
A focus on the strategy of circulation, moreover, "encourages the tracing of networks among not only the conventional metropoles [...] but also the other culture capitals of the world" (Friedman 2012, 512). Examples from such diverse culture capitals can be used to form collages, which Friedman describes as "nonhierarchical encounters between works from different parts of the world that are not conventionally read or viewed together to see what insights such juxtapositions might produce" (516). Whereas Anglo-American and African-American chick lit have already been read or viewed together, even if quite often in a somewhat restricted fashion, there are fewer comparisons between chick lit and its variations from the global South, like African chick lit.

Donadio's "Chick-Lit Pandemic" article (2006) concludes with Helen Fielding's statement that "the really interesting thing would be to see chick lit coming out of Africa." Although African chick lit might not have been not a big topic in the mid-2000s, it is worth mentioning that, only a couple of months after Fielding's statement, Chimamanda Ngozi Adichie's short story "The Thing Around Your Neck" (2006) was published in a collection with the significant title This Is Not Chick Lit: Original Short Stories by America's Best Women Writers. In this anthology, Adichie, born and raised in Nigeria, is considered to be an American writer because she moved to the US at the age of nineteen and still partly lives there. Heather Hewett (2010), on the other hand, mentions Adichie alongside Adaobi Tricia Nwaubani and Petina Gappah as probably the first and most visible authors of "a new generation of African Women Writers" who "make New Waves" exploring "such issues as everyday life, domesticity, female desire, resilience, and globalization." The British writer of Nigerian and Ghanaian origin Taiye Selasi (2005) settles neither for "American" nor for "African," but for "Afropolitan," a term she popularized for a new generation of cosmopolitans with African backgrounds "who belong to no single geography, but feel at home in many" - in Ghana or Nigeria as well as in Great Britain or in the US. Therefore, Adichie's story, which deals with migration, settling in, and cultural hybridity, might be called Afropolitan literature. But then again, Adichie would probably disapprove as she finds the term "Afropolitan" "very annoying": "I'm not an Afropolitan. I'm African, happily so," she says in an interview. "I'm comfortable in the world, and it's not that unusual. Many Africans are happily African and don't think they need a new term" (quoted in Barber 2013). ${ }^{7}$ In any case, these accounts do not give the impression that Africa was not ready for chick lit. It rather seems as if some wo-

7 In a recent call for papers, Afropolitanism has been described as "contradictory and controversial: it is liberating but confining, African but western-orientated, and academic but steeped in popular culture” (Hodapp 2017). For further information regarding Afropolitanism and/in literature, see Knudsen and Rahbek (2016). 
men writers with African backgrounds, along with their publishers, quite consciously distanced themselves from this kind of export label, or even decided, in the case of Selasi, to create their own - no less controversial - labels instead.

That does not mean that there is no "chick lit coming out of Africa" (Donadio 2006). In 2014, some articles were published with headlines like "Where's the African Chick-Lit?” (Abrams 2014) or "Is There a Chick-Lit Gap in African Literature?” (Owino 2014), promoting chick lit written by, about, and for young black African women. However, to write of "the" African chick lit as if it were a phenomenon concerning the whole continent in similar ways can be irritating. According to my research, only three publishers in two out of fifty-four African countries used the label with a relatively broad impact, and then only temporarily and, in part, for quite different products.

In 2010, South African Kwela Books introduced the imprint Sapphire Press, which was described as "Chick Lit for Black Diamonds" (Sitole 2010). In the same year, they published, albeit in their general fiction section, Cynthia Jele's Happiness is a Four-Letter Word (2010), which was marketed as an African version of Sex and the City (Kwela Books n.d.). Furthermore, it is the first book by a South African black female author that was adapted as a film. Jele said in an interview that "books with strong female characters like Bridget Jones's Diary by Helen Fielding" inspired her, "but before all of that there was Terry McMillan's Waiting to Exhale" (quoted in Tshikhudo 2015). Also in 2010, the South Africa-based MME Media Group started Nollybooks, a series of easy-to-read, chick-lit romance fiction titles with South African storylines and characters. These bookazines, a combination of the book and magazine format, are cheap, rather short, and interactive, with word puzzles, quizzes, and a glossary of difficult words at the back - features that according to Nollybooks founder Moky Makura appeal to the local, mostly poor, and often partially illiterate black audience. In contrast to Sapphire Press, and chick lit in general, there are no sex scenes included "because of the high incidence of AIDS in South Africa” (Mabuse and Wither 2011). Christopher Warnes (2014, 154) claims that the South African novels "represent [...] a new departure in South African writing: the arrival in prose form of the mass-produced fantasy for black women," a development which would not have been possible under apartheid, "a system in which legalized racism colluded with patriarchy to position black women as the most subjugated in an already oppressive society" (155). Three years later, in 2013, StoryMoja, a publishing house in Kenya, launched the DrumbeatRomance-Series. There was "a call for authors to submit chick lit stories with the intention of creating a local version of the UK's Mills and Boon in e-Book format" (Abrams 2014). Their initial plan was to tie in with the success of the non-novelistic, already existing chick-lit genre in Kenyan monthly magazines and weekly newspaper pull-outs. 
Right now, there is not much discussion surrounding those imprints, which were, according to the media, supposed to close the African chick-lit gap. Either this gap was not so large after all, or, more likely, the label just did not stand the test. In any case, the product - contemporary Anglophone romance novels with African settings and storylines, and strong female characters - continues to exist without the label. The collage of labels for contemporary African women's fiction indicates that the use of a lingua franca and of established genre or labelling conventions - both guarantors for a certain amount of visibility can be useful, sometimes even necessary steps towards a diversification of the local literary landscape. Despite the partial incorporation of Western forms, the products do not necessarily equate to a simple imitation of an Anglo-American prototype, but rather comply with a form of cultural mimesis: "the imitation of others' representational forms, with a difference” (Friedman 2012, 512; emphasis in original).

\section{Conclusion: Ethnic chick lit between reproduction and resistance}

I have attempted to show that certain binary and distinguishing concepts like genre/subgenre, chick lit/ethnic chick lit, and Anglo-/African-American/African chick lit, which go hand-in-hand with the West vs the rest dichotomy, are able to disguise and even to whiten a literary tradition. A re-visioning of the global phenomenon of "ethnic" chick lit has demonstrated that there are usually more than two sides to recover. "The West" is not solely composed of Anglo-American chick lit from the UK and the US, just as "the rest" does not constitute a homogeneous "ethnic" mass. While the recovery of African-American chick lit has clarified that most certainly no transfer took place of Bridget Jones's Diary to Terry McMillan, such a transfer did take place to Africa. Still, the circulation strategy indicates that the new generation of African, American, or Afropolitan women writers seems more to reject than to embrace the label ("This Is Not Chick Lit"), or else to coin a new one (Afropolitan literature), like Guerrero (sistah lit) did to designate African-American chick lit. Starting in 2010, however, some African publishers made an effort to establish the chick-lit label for contemporary women's fiction, mostly set in local urban environments, featuring young and independent black female protagonists. To write too generally of "chick lit coming out of Africa” (Donadio 2006) is, nevertheless, inadequate, as only three publishers (Kwela Books, MME Media, and StoryMoja) from two African countries (South Africa and Kenya) have made an effort to sell fiction under this label so far. The collage of their short-lived 
imprints indicates that the chick-lit label has not proved entirely applicable to the context of African literatures and cultures.

Altogether, the distant comparison of African-American and African chick lit permits two conclusions. First, the classification of popular fiction by women with non-Western sociocultural backgrounds as an "ethnic" subgenre and variation of an Anglo-American original not only demonstrates existing inequalities in the literary market, which include gender and ethnic biases, but also helps to reproduce them. The resistance of some authors of colour to accept such ethnicized labels unquestioningly, might, on the other hand, also be interpreted as pointing to their agency rather than to their lack of power over a discourse that is so overtly racist and sexist as that of chick lit.

\section{Works cited}

Abrams, Dennis. “Where’s the African Chick-Lit?” Publishing Perspectives 7 April 2014. http:// publishingperspectives.com/2014/04/wheres-the-african-chick-lit/ (15 September 2017).

Adichie, Chimamanda Ngozi. “The Thing around Your Neck." This Is Not Chick Lit: Original Stories by America's Best Women Writers. Ed. Elizabeth Merrick. New York: Random House, 2006. 3-13.

Apter, Emily S. Against World Literature: On the Politics of Untranslatability. London: Verso, 2013.

Baldick, Chris. "Chick Lit." The Oxford Dictionary of Literary Terms. 4th ed. Oxford: Oxford University Press, 2015. 57-58.

Barber, John. "New Novel Shows that Chimamanda Ngozi Adichie Gets the Race Thing." The Globe and Mail 9 June 2013. https://beta.theglobeandmail.com/arts/books-and-media/ new-novel-shows-that-chimamanda-ngozi-adichie-gets-the-race-thing/article12423909/? ref=http://www.theglobeandmail.com\& (21 September 2017).

Betterton, Don M. Alma Mater: Unusual Stories and Little-Known Facts from America's College Campuses. Princeton: Peterson's Guides, 1988.

Casanova, Pascale. La République mondiale des lettres. Paris: Seuil, 1999.

Chen, Eva. "Shanghai(ed) Babies: Geopolitics, Biopolitics and the Global Chick Lit." Feminist Media Studies 12.2 (2012): 214-228.

“Chick Lit.” Wikipedia. 2018. https://en.wikipedia.org/wiki/Chick_lit (29 December 2018).

Damrosch, David. What Is World Literature? Princeton: Princeton University Press, 2003.

Donadio, Rachel. “The Chick-Lit Pandemic.” The New York Times 19 March 2006. http://www. nytimes.com/2006/03/19/books/review/the-chicklit-pandemic.html (15 September 2017).

Dyer, Richard. White. London and New York: Routledge, 2008.

Ferriss, Suzanne, and Mallory Young. “Introduction.” Chick Lit: The New Woman's Fiction. Ed. Ferriss and Young. New York: Routledge, 2006. 1-13.

Folie, Sandra. “Chick Lit Gone Ethnic, Chick Lit Gone Global?! Die Rezeption eines transnationalen Genres im plural-queeren Vergleich.” Open Gender Journal 2 (2018): 1-20. https://doi. org/10.17169/ogj.2018.21 (4 February 2019).

Folie, Sandra, and Andrea Kreuter: “Ausschnitt M|macht Gattung: Zum Verhältnis von Gattungskommentar und Gattungs(re)konfiguration.” Der Zeitungsausschnitt: Begleitbuch zur 
Ringvorlesung. Ed. Thomas Ballhausen and Robert Huez. Vienna: danzig \& unfried, 2018. 43-65.

Friedman, Susan Stanford. "World Modernisms, World Literature, and Comparativity." The Oxford Handbook of Global Modernisms. Ed. Mark A. Wollaeger and Matt Eatough. Oxford: Oxford University Press, 2012. 499-525.

Guerrero, Lisa A. “'Sistahs Are Doin' It for Themselves': Chick Lit in Black and White.” Chick Lit: The New Woman's Fiction. Ed. Suzanne Ferriss and Mallory Young. New York: Routledge, 2006. 87-101.

Guillory, John. Cultural Capital: The Problem of Literary Canon Formation. Chicago: University of Chicago Press, 1993.

Gunne, Sorcha. “World-Literature, World-Systems, and Irish Chick Lit.” Globalizing Literary Genres: Literature, History, Modernity. Ed. Jernej Habjan and Fabienne Imlinger. New York: Routledge, 2016. 241-253.

Hedrick, Tace. Chica Lit: Popular Latina Fiction and Americanization in the Twenty-First Century. Pittsburgh: Pittsburgh University Press, 2015. Latino and Latin American Profiles.

Hegde, Radha S. "Gender, Media, and Trans/National Spaces." The Routledge Companion to Media and Gender. Ed. Cynthia Carter, Linda Steiner, and Lisa McLaughlin. New York: Routledge, 2014. 92-101.

Hewett, Heather. "A New Generation of African Women Writers Make New Waves." Women News Network. 8 August 2010. https://womennewsnetwork.net/2010/08/08/new-gen-africawomen-authors/ (15 September 2017).

Hodapp, James. “CfP: Afropolitan Literature as World Literature.” Africa in Words. 18 June 2017. https://africainwords.com/2017/06/18/cfp-afropolitan-literature-as-world-literature-deadline-1-august-2017/ (21 September 2017).

Knudsen, Eva Rask, and Ulla Rahbek. In Search of the Afropolitan: Encounters, Conversations, and Contemporary Diasporic African Literature. Lanham: Rowman \& Littlefield, 2016.

Konchar Farr, Cecilia. "It Was Chick Lit All Along: The Gendering of a Genre." You've Come A Long Way, Baby: Women, Politics, and Popular Culture. Ed. Lilly Goren. Kentucky: University Press of Kentucky, 2009. 201-214.

Kwela Books. "Happiness is a Four-Letter Word, Cynthia Jele." www.kwela.com. n.d. http://www. kwela.com/Books/19281 (17 October 2018).

Lee, Felicia R. "Black Chick Lit Hits Middle Age." Star-News 7 March 2005: 6D. https://news. google.com $/$ newspapers?nid=1454\&dat=20050703\&id=3HOWAAAAIBAJ\&sjid=qR8EAAAAI BAJ\&pg=4937,621174\&hl=de (15 September 2017).

Mabuse, Nkepile, and Emily Wither. "New Wave of Chick Lit Has Romance - but No Sex." CNN. 16 February 2011. http://edition.cnn.com/2011/WORLD/africa/02/16/nollybooks.romance. reading/ (15 September 2017).

Mazza, Cris. "Who's Laughing Now? A Short History of Chick Lit and the Perversion of a Genre." Chick Lit: The New Woman's Fiction. Ed. Suzanne Ferriss and Mallory Young. New York: Routledge, 2006. 17-28.

Mazza, Cris, and Jeffrey DeShell, eds. Chick Lit: Postfeminist Fiction. Carbondale: Fiction Collective 2, 1995.

Missler, Heike. The Cultural Politics of Chick Lit: Popular Fiction, Postfeminism and Representation. New York and London: Routledge, 2016.

Moretti, Franco. "Conjectures on World Literature." New Left Review 1 (2000): 54-68.

Mufti, Aamir R. Forget English! Orientalisms and World Literatures. Cambridge and London: Harvard University Press, 2016. 
Owino, Anjellah. “Is There a Chick-Lit Gap in African Literature?” Standard Digital 30 March 2014. http://www.standardmedia.co.ke/article/2000108129/is-there-a-chick-lit-gap-in-africanliterature (15 September 2017).

Peitz, Annette. Chick Lit: Genrekonstituierende Untersuchungen unter anglo-amerikanischem Einfluss. Frankfurt am Main: Lang, 2010.

Ponzanesi, Sandra. The Postcolonial Cultural Industry: Icons, Markets, Mythologies. Basingstoke: Palgrave Macmillan, 2014.

Prendergast, Christopher. “The World Republic of Letters." Debating World Literature. Ed. Benedict Anderson and Prendergast. London and New York: Verso, 2004. 1-25.

Saussy, Haun. "Comparative Literature: The Next Ten Years." State of the Discipline Report. 3 September 2014. http://stateofthediscipline.acla.org/entry/comparative-literature-nextten-years (15 September 2017).

Selasi, Taiye. “Bye-Bye Babar.” The LIP Magazine 3 March 2005. http://thelip.robertsharp.co.uk/ $? p=76$ (15 September 2017).

Sitole, Ayanda. “Chick Lit for Black Diamonds.” Mail\&Guardian 30 September 2010. http://mg. co.za/article/2010-09-28-chicklit-for-black-diamonds/ (15 September 2017).

Skurnick, Lizzie. "Chick Lit 101: A Sex-Soaked, Candy-Colored, Indiscreet Romp through the Hottest Gal Tales of the Season.” Orlando Weekly 20 November 2003. http://www.orlando weekly.com/orlando/chick-lit-101/Content?oid=2260390 (15 September 2017).

Spivak, Gayatri Chakravorty. Death of a Discipline. New York: Columbia University Press, 2003.

Tshikhudo, Mpho. "South African 'Chick-Lit' Heads to the Big Screen.” Mail\&Guardian 2 October 2015. http://mg.co.za/article/2015-10-01-south-african-chick-lit-heads-for-the-film-indus try/ (21 September 2017).

Vnuk, Rebecca. “'Chick Lit’: Hip Lit for Hip Chicks. Collection Development.” Library Journal 15 July 2005. https://web.archive.org/web/20101201234015/http://www.libraryjournal.com/ article/CA623004.html (2 January 2019).

Warnes, Christopher. "Desired State: Black Economic Empowerment and the South African Popular Romance." Popular Culture in Africa: The Episteme of the Everyday. Ed. Stephanie Newell. New York: Routledge, 2014. 154-171.

Whelehan, Imelda. The Feminist Bestseller: From "Sex and the Single Girl" to "Sex and the City." New York: Palgrave Macmillan, 2005.

Wright, Abbe. “Terry McMillan on No More “Chick Lit.” YouTube. 2016. https://www.youtube. com/watch?v=AtQUGSZWgAU (18 October 2018).

Yardley, Cathy. Will Write for Shoes: How to Write a Chick Lit Novel. New York: St. Martin's Press, 2006.

Dr. Sandra Folie, BA MA MA, is an assistant at the Department of Comparative Literature at the University of Vienna. Her research interests are feminist studies, gender studies, as well as intersectional studies, the sociology of literature, women's fiction, and world literatures. 
